\title{
Tischner as a metapolitician
}

\section{Krzysztof Wieczorek ${ }^{1}$ (1)}

Published online: 25 November 2019

(c) The Author(s) 2019

\begin{abstract}
Józef Tischner, a Polish philosopher and a seasoned commentator on the political transformations associated with the decline of communism and the building of a new democratic order in the final decades of the twentieth century, was, and still is, a controversial figure. Some see him as a profound philosopher, others as a moral authority, while others see him as a political opponent. I discuss the question concerning where Józef Tischner drew the line between political engagement sensu stricto and metapolitics, which is philosophically and programmatically grounded and neutral to the differences in world views. I inquire whether it is legitimate to attribute to Tischner political views and sympathies sometimes referred to as leftwing Christian liberalism and whether these views influenced the structure and the main theses of Tischner's metapolitical thought. I attempt a reconstruction of Tischner's position and indicate its basis in the assumptions of Christian personalism, the philosophy of dialogue, and the ethics of solidarity.
\end{abstract}

Keywords Tischner $\cdot$ Metapolitics $\cdot$ Public involvement $\cdot$ Dialogue $\cdot$ Solidarity Post-communism

\section{Tischner and politics}

Józef Tischner (1931-2000) was one of the most eminent philosophers in post-war Poland and an important figure in Polish public life in the 1980s and 1990s. For those with liberal-democratic views, he was recognised as an authority in matters of the social ethics and supra-particular moral norms that should apply in the sphere of political actions. His reflections, analyses, and diagnoses of key phenomena in public life accompanied the successive stages of the changes in Polish political reality: from the times of the so-called real socialism through a confrontation of power with the democratic opposition, martial law, and political transformation.

Krzysztof Wieczorek

krzysztof.t.wieczorek@us.edu.pl

1 Institute of Philosophy, University of Silesia, Katowice, Poland 
Tischner thought, wrote and evaluated reality as a philosopher. However, the reception of his books, articles, and public speeches went far beyond the philosophical dimension. Some, especially his opponents, who represented extremely different beliefs, considered him to be a politician. At the same time, they accused him of illegitimate interference in political practice. The main reason for this was Tischner's unambiguous support for the values that constitute the ethos of civil society. This was inconvenient for both the party and state authorities of the communist era, as well as for a wide range of post-communist circles that built their ethos on the idea of a strong state and the conjunction of patriotic and Christian values. However, is the acceptance of a certain system of values that determine a balanced model of the relationships between those in power and those in society enough to recognise someone as a politician and accuse them of bias in a political struggle?

Ludwik Wisniewski (b. 1936), a Polish Dominican who was also charged with political involvement in opposition to the government, put forward the following argument:

I've never delivered nor am I delivering political sermons. I clearly distinguish between politics and metapolitics. Politics is the art of gaining power and ruling. Metapolitics is a defence of the values on which the state should be built. (Wisniewski 2019, p. 14)

In writing these words, he used the term "metapolitics," which had been in use in the social sciences since the end of the eighteenth century, and stressed its separation from politics. Is this correct? An analysis of the dictionary and contextual definitions of the terms (see Gregor 2014; Pięta-Szawara 2013, Weber 1992) justifies the interpretation according to which political activity is either the desire to participate in the exercise of power by belonging to or actively supporting a particular individual or political party or the direct participation in the institutions of the apparatus of power. By contrast, the activity of commenting, giving opinions or criticising the actions of the authorities and political parties is classified as metapolitics. However, there is another view that the extent of the term 'policy' is much broader. It also includes publicly taking a position on matters that are the subject of ongoing disputes in public life and expressing this position in speech and writing. As Andrew Heywood rightly pointed out:

Regardless of what else politics may be, it is a social activity that takes place through language, whether it is written in books, pamphlets and manifestos, scribbled on posters and walls, or spoken at meetings, shouted at rallies and sung at demonstrations and marches.... Language is ... a real and active force that has the ability to ignite imagination and arouse emotions.... Language thus helps to create the world in effect. This problem becomes particularly important in politics. (Heywood 2004, p. 14)

It is therefore questionable whether a policy should be distinguished from metapolitics or whether metapolitics should be considered to be an integral part of a policy. For my deliberations, it is irrelevant whether or not metapolitics is 
considered to be a form of political action. My aim is to explore and reconstruct Tischner's metapolitical views. In light of the allegations he has been facing, however, I would like to address the following problem: did his writing and public statements fall within the limits of metapolitics, where he should have been impartial towards ongoing disputes and the political struggle, or did he himself become a party to those disputes?

In analysing Tischner's work, Zbigniew Stawrowski, who, incidentally, accused himself of being on the side of a lie, gives examples that indicate that he sometimes "fell into the trap of political reason" (Stawrowski 2004, p. 73). The difficulty in deciding whether this was really the case lies in the fact that "in the political space, truth is at most a means, while the goal is to reform the world" (Bobko 2004, p. 37). If this is the case, then there is no objective criterion for evaluating the individual projects of world reform that are submitted by the various political circles. "For there is no source of truth that can be relied on with confidence to repair the world" (Bobko 2004, p. 39). And where the source of truth is not visible, it is easy to "err in the element of truth" (Tischner 1998a, p. 140).

Tischner's defence of his own political sympathies and antipathies was also a "defence of the values on which the state should be built" (Wisniewski 2019, p. 14). These values are revealed to the philosopher by means of phenomenological analyses. It may have happened, however, that the philosopher also succumbed to illusion. In Tischner's opinion, the source of illusion could have been hope for the absolute superiority of one political project over all others. I leave this question unanswered. Instead, I will focus on the following question: what valuable and innovative features does Tischner's metapolitics project have? Undoubtedly, one can distinguish a corpus of Tischner's texts from which the project can be extracted. Without aspiring to indicate all of the articles and fragments of books that exploit metapolitical issues, I would like to draw below a picture that emerges from a critical reading of a few selected publications, which I will point out later in the article.

\section{Who was Józef Tischner as a committed participant in public life?}

In his case, involvement in the political dimension of public life did not cover only the area of philosophical analysis. His image as a well-known and popular figure, though at the same time judged very differently (he had many friends and fierce enemies), contains three complementary profiles. To bring this issue closer, let us quote the words of his student and researcher of his intellectual legacy, Jarosław Gowin:

Who was Father Tischner? He used to say about himself... that he was first a human being, then a philosopher, and only at the end a priest.... I leave it to the curiosity of future researchers to determine how much as a philosopher he owed to Hegel, phenomenology or the philosophy of dialogue.... However, I am deeply convinced that without taking philosophical views into account, it is 
impossible to grasp the sense of his religious or political views. (Gowin 2003, pp. 10-11)

What axiological order can be derived from the foregoing (not merely humorous) self-presentation: Tischner the man-philosopher-priest? As a human being, Tischner was deeply attached to Poland, whose fate was in his heart, and to whose prosperity he tried to contribute with his work. He devoted a large part of his scientific, journalistic and pastoral activities (sermons and retreats) to a special kind of service to his homeland, namely, exploring and critically evaluating the national characteristics of Poles in order to better understand his compatriots and their homeland and to seek a remedy for their "spiritual poverty"1 even more effectively. The first text by Tischner- "Contributions to Research on the Structure of Polish Poviat Catholicism," published in Więz in 1960-was dedicated to these issues, and the most important of his texts, whose theses echoed widely beyond philosophical circles, include: a comprehensive essay: "Chochoł sarmackiej melancholii" [The strawman of Sarmation melancholy] (Znak 1970, 10 (196), pp. 1243-1254) and the books: Polski ksztatt dialogu [The shape of Polish dialogue], Paris 1981; Polska jest ojczyzna [Poland is a fatherland], Paris 1985, and Polski mtyn [The Polish mill], Kraków 1991.

As a philosopher, apart from the strictly philosophical problems connected with, among other interests, the phenomenology of the structures of ego-consciousness or the author's reflections on the axiological self, he also posed questions that arose directly from the rhythm of the rapidly changing political events in Polish collective life. Three of these kinds of questions, to which he sought answers using inspirations from contemporary philosophy, ${ }^{2}$ can be found, each determining, according to Tischner, the most important problem of political philosophy with regard to the issues of the passing decades of the twentieth century. As the social and political situation changed over time, so did the questions.

The first seems to mark the horizon of Tischner's reflections in the 1960-1980s, and can be formulated as follows: Why do Poles accept a political system based on lies, injustice, and violence? The second one, which emerged from the surprising events of the Polish national awakening in the late 1970s and its culmination in 1980-1981, is: Is it possible in the present geopolitical conditions, while taking into account the internal balance of power in the country, to reach a morally acceptable agreement between the state power and the democratic opposition? The third issue, in the aftermath of the catastrophic breakdown of dialogue as a result of the introduction of martial law in Poland that later marked the difficult

\footnotetext{
1 " $[\mathrm{C}]$ onscience says... that it is not ethically indifferent to practice a particular pastoral activity in a particular poverty of the world", wrote Tischner (1982, p. 299). Gowin comments on this thought as follows: "For the lack of sensitivity to the poverty of a concrete person, to the evil that affects him... Father Tischner accused Thomism" (Gowin 2003, p. 39).

2 Jarosław Jagiełło emphasizes: "[Józef Tischner] analyzed the surrounding reality not with the use of philosophical methods, which he learned during his studies of the distant history of philosophy, but... with the use of this method, the spectacular development of which took place during the time in which he lived. It was a phenomenological-hermeneutical method. He studied it mainly from Husserl, Heidegger, Levinas, Gadamer and Ricoeur” (Jagiełło 2005, p. 9).
} 
and often disappointing attempts at restructuring Polish policy, was: What do Polish politics lack?

I will return to these questions and propose answers later in the text. Now, I still have to complete the picture of the triad referred to by Gowin. So, who was Tischner as a priest? There is no place here to engage in a detailed reconstruction of the figure of Tischner the reverend, so let us stick to sketching out a few of the most important features. First of all, he proclaimed the Good News to all people in all circumstances, i.e., pre-school children (the famous masses for children in the Church of St. Mark in Kraków), workers [for whom he acted as an informal chaplain of the NSZZ 'Solidarność' (Solidarity)], highlanders (for many years he was a chaplain of the Association of the People of Podhale), intellectuals (he often participated in the meetings that were organised nationwide by the regional branches of the Catholic Intelligence Clubs known as Christian Culture Days), unbelievers and those searching (he was widely known as a priest of exceptional openness, and was friends with people with left-wing views, including Adam Michnik). Secondly, he was characterized by a deep sense of responsibility for the face of the Polish Church. He cared about it and tried to ensure that the clergy and laity representing the Catholic ethos did not bring shame and scandal, but who, through their own lives, gave testimony to their faithfulness to the ideals of the Gospel (he dedicated to this subject, among others, the book entitled Ksiadz na manowcach). Thirdly, he attached great importance to the relationship between the Church and the structures of state power. He spoke with approval of the steadfast attitude of the clergy and laity in the years of the communist persecution of the Church, and he wrote with admiration about the role of Catholic authorities as mediators during times of social tensions, strikes, and repressions, while he observed, with concern and anxiety, the changes taking place in the Polish Church in the newly emerging postcommunist liberal-democratic state.

\section{Józef Tischner's philosophical questions}

The above combination of the three dimensions of activity, each of which is subordinated to a consciously constructed scale of values, reveals Józef Tischner as a rather unusual and exceptional intellectual. Jarosław Jagiełło, along with J. Gowin another student and continuator of Tischner's thoughts, writes about him:

[he] was a philosopher who was particularly sensitive to everything that was happening around him. He was able to combine thinking with life.... In the centre of his thinking was a concrete man living between the Tatra Mountains and the Baltic Sea, who had to be helped to deal with [his] problems. (Jagiełło 2005, p. 9) 
This peculiarly directed intellectual and emotional sensitivity, which was a source of many of the grievances, worries, and misunderstandings ${ }^{3}$ that accompanied his academic and public activities, meant, among other things, that despite his huge intellectual potential, which predestined him to play a significant role in world philosophy, he never decided to become a 'philosopher from behind the desk', patiently and precisely analyzing abstract problems. Philosophy was not his goal, but his means. To what? One of the most frequently quoted fragments of his writing is the following:

It seems to me that before any philosophizing, especially in our country, we have to make an important choice: we have to choose, from what we can think, what we have to think about. And what we need to think about does not come from the pages of a book, but instead from the face of a man concerned about his fate. Once philosophy was born out of wonder for the world around us (Aristotle). And then also doubt (Descartes). Now, on our Earth, it is born out of pain. The quality of philosophy is determined by the quality of human pain, which philosophy wants to express and which it wants to remedy. Whoever does not see this is close to betrayal. (Tischner 1982, p. 13)

One of the types of pain that Joseph Tischner wanted to actively counteract, as a thinker and as an important actor in the national public life, is the spiritual pain born out of a sense of social injustice or deep dissatisfaction with the way that the state is governed. Tischner knew this kind of pain very well. He experienced it often himself, but he also knew-mainly from his pastoral practice, from meetings with people seeking spiritual advice - the negative consequences it brings about in the soul and in the human community. One of the possible therapies for this pain is strictly political activity that is aimed at overcoming the sources of injustice and that strives to change governments for the better. However, Tischner did not engage in this type of activity. He stood by, watched, analyzed, asked questions and used his competence to find the best answers. Among the questions he considered, the three mentioned at the beginning of the article played key roles. Let us now recall them in order to extract from the texts of the Kraków thinker elements from which one can try to formulate answers.

The first question, in reference to the times of the People's Republic of Poland, is: Why do Poles accept a political system that is based on lies, injustice, and violence?

The earliest attempt at an answer can be found in an essay from 1970: "Chochoł sarmackiej melancholii," which discusses the fact that Poles (hidden under the symbolic name of Sarmatians) have a historically conditioned tendency to derive perverse

\footnotetext{
3 Jarosław Gowin writes about how various misunderstandings influenced the reception of Tischner's thoughts: "Despite the enormous popularity that surrounded him, especially after 1989, the author of The World of Human Hope had a sense of misunderstanding. Those who knew him better know how much he valued serious opponents.... But such opponents were rare. In general, the criticism that fell on him from many sides came from misunderstandings... I came to the conviction that the living memory of the person of Fr Tischner is accompanied by the rapid imprisonment of his so creative thoughts in a few false or simplistic stereotypes" (Gowin 2003, pp. 5-6).
} 
pleasure from their own failures and to accept the inevitability of the judgments of history, even the most tragic ones, in a melancholy way. This tendency-these are only the implied conclusions drawn from reading the essay in its historical context — disarms the will of the nation to resist and gives passive consent to the anti-democratic methods of government.

Further contemplation of the question brings slightly different conclusions. In a speech in 1980, Tischner tried to find as many reasons as possible for an optimistic assessment of current events. Among other things, he emphasised the positive evolution of the state power elites in the past decades-passing from the acceptance of revolutionary terror methods to the search for 'socialism with a human face' (see Tischner 1981a, p. 14), and from a ruthless fight against the class enemy to a genuine dialogue on a relatively broad range of common values. In the Polski ksztalt dialogu, the author wrote:

For more than thirty-five years, we have had a unique encounter between Christianity and Marxist socialism... two opposing concepts of making people happy. This meeting... is sometimes called a dialogue, more often a dispute, a confrontation, a struggle - because of the tone that currently dominates it.... The Christian idea and the socialist idea seem contradictory. But the historical conditions in Poland are such that both of these ideas must live together and determine the history of the nation together. (Tischner 1981a, p. 9)

Elsewhere, Tischner attempts to understand the subjectively good intentions of some high-ranking communist officials-for example, when he quotes Jakub Berman's explanation of the political strategy in building relations between Poland and the USSR:

Poland is on the road between the Soviet Union and Western Europe and its position is clear:... either America will manage to create a ferment here... and then there will be intervention and bloodshed,... or the entire block will fail,... or the Third World War will break out. I do not see any other perspectives. (Statement by J. Berman, quoted in: Tischner 1991, p. 123)

In his commentary, Tischner shows the falsity of the conclusions, but does not deny the good will and the peculiarly understood concern for the common good of the Polish nation in the conditions of a geopolitical dependence on a great power. And where good intentions can be found in the actions of the authorities, it is easier to accept the solutions imposed on society by those authorities.

Even later, in Tischner's deliberations, another motif appears, which is related to the sociological category of homo sovieticus. The hypothesis is as follows: after years of forced coexistence of a reluctant society with unwanted power, a kind of symbiosis has developed, a form of quasi-biological adaptation to a pathological system (see Tischner 2005, pp. 141-145). This mechanism also had a real impact on the level of the social acceptance of a defective and inefficient system of governance. 


\section{Tischner and the last years of the People's Republic of Poland}

In the recent history of Poland, however, the time had come when the capital of trust in the state power has been almost completely exhausted. This resulted in a growing escalation of resistance and social protest, which took place between 1976 and 1981 (see Piasecki and Michalak 2016). However, the strategy of power towards social resistance also changed. Faced with the failure of its attempts to intimidate society and the ineffectiveness of the violence against disobedient people, conciliatory attitudes gradually began to prevail. This was largely due to the fact that those in power were more and more aware of the loss of support and social legitimacy (cf. Kofta and Leszczyński 2019, p. 21). As a response to this situation, the will to 'lay the foundations for an authentic discussion' appeared (Kofta and Leszczyński 2019, p. 24), followed by action. It was also possible to create an institutional framework for the dialogue between the authorities and society because society had gradually ceased to be an amorphous mass of atomised and politically incapacitated subjects of the apparatus of power. It began to organise itself from the bottom up, revealing new forms of civic movement with which the authorities could establish relations and seek a broad understanding. In this way, the authorities sought to rebuild their lost legitimacy. This new situation also required a new assessment from the perspective of the ethos of public life. The dilemma of whether to support the aspirations of the government, which had no mandate to trust the citizens, to re-enforce its hegemony, or to use its weakness to force the desired reforms from below, for example, in the social sector, was not easy to solve. Hence, Tischner's metapolitical thinking raised a new question: in the current geopolitical conditions and considering the internal balance of power in the country, was it possible to reach a morally acceptable agreement between state power and the democratic opposition?

Tischner entered this debate with a previously developed conviction that, on the one hand, there are influential personalities among government officials who sincerely want to build social dialogue as a new basis for legitimacy of the political system, while on the other hand, the newly emerging civil society elites are largely composed of people with a Catholic worldview shaped by the spirit of Vatican II, and therefore, were open to dialogue with the modern world. Abandoning or breaking off the dialogue will inevitably lead to open confrontation, the consequences of which may be tragic for the country. For these reasons, he became an ardent advocate of the idea of national understanding. As a philosopher-and, let us add, as a metapolitician (according to the definition of metapolitics proposed by Wisniewski) - he considered it necessary to consolidate this attitude on the foundation of a value on which 'the state should be built' (Wisniewski, p. 14). The value he chose was solidarity.

In October 1980, the 43rd issue of the Catholic weekly from Kraków Tygodnik Powszechny published a text entitled "Solidarność sumień" (The solidarity of the many consciences) - a record of Father Tischner's sermon from the Wawel Cathedral from 19th October. His first words were: 
Today we bring to the Wawel Hill matters closest to our hearts. These matters are summarized in one word - the word 'solidarity'. This word binds together people who only yesterday were far apart from each other... in order to give a new shape to our days. (Tischner 1981a, p. 5)

It is hard to find a clearer declaration: the main concern of Poles today should be the agreement between "people who only yesterday stood far apart from each other" - no one at that time had any doubts about the people he had in mind.

Another motif was the decision to base the postulated idea and practice of interpersonal solidarity directly on the Gospel and on the message of Jesus:

If the meaning of the word 'solidarity' had to be defined more precisely, it would be necessary to refer to the Gospel and look for its origin there. The meaning of this word is defined by Christ: 'Carry each other's burdens and thus you will fulfil the law of God.' (Ibid., p. 6)

Another foundation of solidarity, which is indicated later in the text, is an axiological idea of Kantian provenance-the idea of the essentially good will of man.

The virtue of solidarity is an expression of the good will of man. In fact, we are all solidary, because we are all people of good will in the depths of our souls. (Ibid., p. 7)

Finally, the most important element of Tischner's thinking, that necessarily results from the foundation of the Gospel and the a priori principle of absolute goodwill, is the inclusive rather than exclusive character of solidarity:

solidarity, born of the letter and the spirit of the Gospel, does not need an enemy or adversary to strengthen and develop itself. It turns to all, not against anyone. (Ibid.)

This is, I believe, the central point of Tischner's metapolitics, and at the same time, the most original and radical feature of his attitude towards the formation of an ethos of society, which emerges from an age of permanent struggle against conflicting interests and an awakening to a new form of the solidary community. Tischner considers a realistic and achievable goal-or at least one worthy of concrete and immediate efforts-viz., the rebuilding of the social imaginary to replace the pagan (or Gnostic) idea of the 'solidarity of the good against the evil' with a much more sophisticated and subtle idea, closer to the spirit of the Gospel: that of 'solidarity of all with all'. This vision is not about the prospect of taking power, nor about demanding 'historical justice' and consistent accountability for the guilt of those in power, but about something prior and more elementary: the recognition of the personal dignity and subjectivity of each individual, regardless of his views and actions, and the courage to trust in the good will of others. As Alexander Bobko writes:

because of that the matter of existential truth becomes our common cause - we reach it not by acting against one another or by competing with each other, but through mutual care and sacrifice, through reciprocity of testimony. (Bobko 2004, p. 35) 
Whether Tischner's model of inclusive solidarity was understood and captured within the groupings that were building the new structures of civil society at the beginning of the 1980s is a completely different issue. An analysis of the history of the social movement, which (independent of Tischner) adopted the notion of "solidarity" as its emblem, which then led to the creation and legalisation of a trade union with this name, independent of the state authorities (registered in October 1980), shows that the traditional model of solidarity ('solidarity against one another'), which had been practiced many times (albeit under different names and signs) but which lacked any real moral potential for rebirth, was soon victorious there. Equally quickly, a collective sense of moral superiority appeared in this movement, in whose name a number of demands and postulates were put forward. The efforts of the chaplain of NSZZ 'Solidarność', whose aim it was to establish a genuinely evangelical and conscious ethical foundation of the movement including moral imperatives, were of little use. These efforts included two types of activity: writing and pastoral work. The first resulted in the publication of a series of 21 articles in Tygodnik Powszechny, which were collected and published in August 1981 in a separate volume entitled Etyka Solidarności, Kraków: Znak 1981. The book became a worldwide showpiece of Polish transformations-within a few years, it had been translated and published in eight languages, including Italian, English and German (cf. Bonowicz 2005, pp. 286-287). The pastoral activity at that time focused primarily on accompanying the processes of building the central and regional structures of the 'Solidarność' trade union, and the main forms of activity were lecturing, celebrating patriotic masses, and preaching sermons (cf. Bonowicz 2001, pp. 336-350).

Józef Tischner perceived a growing divergence in attitudes and opinions among the activists and members of the Union, and at the same time-as an experienced observer of social reality and its ethos-he saw how successive years brought ever greater moral chaos into the entire community of citizens, as well as ever greater confusion and disagreement among the individual circles within the new political class. All of these highly disturbing phenomena in public life led him to reflect on the last of these questions: What does Polish politics lack?

\section{What does Polish politics lack?}

The general answer was: there is no sufficiently durable ethical foundation in Polish political life. To address this lack, Tischner outlined, in his leading work Etyka solidarności, an entire map of the values that, in his opinion, should imbue the ethos of Polish politics. Each of the twenty-one chapters of the book is a mini essay in the philosophy of values "derived from the spirit of phenomenology" (Bonowicz 2001, p. 329) and the "characteristically hermeneutical interpretation of... the ethical substance of human self-awareness" (Karon-Ostrowska 2003, pp. 98-99).

This huge work, however, did not fulfil the hopes that the author had placed in its results. The outstanding biographer of Tischner, Wojciech Bonowicz, comments: 
To some extent Tischner wrote a persuasive book, addressing not only the people of Solidarność but also the people of power, trying to commit both to dialogue, and the latter (at some point Tischner calls them, not without irony, 'brothers- adversaries') to show their place in the ongoing changes. Tischner's effort at persuasion was largely in vain, and the introduction of martial law was the ultimate proof of this. Also, in 'Solidarność' the book could not gain full understanding. (Bonowicz 2001, p. 330)

After experiencing the failure of his project to saturate political life with ethical values, Tischner apparently decided that the solution should be sought more deeply. He decided to return to Hegel.

"I read Hegel in the hot days of our recent history," he confesses to the readers of the book Spowiedź rewolucjonisty [The confession of a revolutionary]. "I have read The Phenomenology of Spirit several times. But the real encounter with this text took place only during the months of martial law, which, according to some, was a 'historical necessity.' There was something astonishing about it: patrols were controlling the streets, and we in the largest university hall considered the march of the spirit of freedom through history" (Tischner 2016, pp. 16 and 20).

Having based himself on Hegel's philosophy, the Kraków thinker asked new questions, about the meaning of history, about the 'power of judgment,' the spirit, the ethical substance, reciprocity, and the relationship of reason to freedom. All of this in order to try to reach the universal sense of the events that were taking place just outside of the walls of the lecture hall. He tries to be not only a philosopher, but also a historian, exploring history in a way that is closest to his heart:

a historian looks at events, especially those that are closest to him,... discovers that they are the only, unique, surprising visionaries and prophets. Nevertheless, he wants to read from them some more or less universal sense, in order to make them subject to the judgment of conscience... The thinking of a historian who is sensitive to values is characterized by the fact that he passes from events to their meaning. (Tischner 1998b, p. 346)

Undoubtedly, Józef Tischner-although he was neither a visionary nor a prophet, but rather a future spiritus movens of the new social ethos-was surprised, or even shocked, by the introduction of martial law. Certainly, he also wanted to understand the meaning of this situation, its causes and consequences. Judging by the content of his last book (Polski ksztatt dialogu), which he completed just before martial law, he noted that one of the most important reasons for the collapse of the mutual aspirations - on the part of both the authorities and the opposition-was the failure to initiate an 'axiological dialogue.'Although there were many different attempts to bring the positions closer together through meetings, talks, and various bilateral committees, these attempts, according to Tischner, did not result in a genuine dialogue. For

dialogue is not the first better conversation between man and man, but only such a conversation in which the testimony of another man is recognized as a 
necessary source of knowledge about the subject of the conversation. (Tischner 1981b, p. 185)

If the discussion concerns the establishment of a catalogue of commonly recognized values, then both sides should listen carefully to the testimonies of axiological experiences. Did this happen? Tischner answers:

I look again at the history of our dialogue. I ask: was there dialogue or was there not? Unfortunately, in my opinion, there was no dialogue. The situation... resembled that of Socrates in prison. This fundamental context of disputes changed the meaning of words, polemics and explanations. A great lesson remained: where the disputing parties do not have full freedom, dialogue is not and cannot be dialogue. (Tischner 1981b, p. 15)

And where there is no dialogue, it is impossible to 'restore the proper hierarchy of values' (ibid., pp. 15-16).

However, a sudden return to the seemingly discredited strategy of basing the authority of the governing bodies on an extensive apparatus of violence must have had deeper causes. Who knows whether one of them-perhaps the most important one-was not the improperly located sense of responsibility within the circle of the highest management of the state and the ruling party-PZPR? This may be indicated by the content of General Jaruzelski's speech proclaiming martial law on 13th December 1981. It contains, among other things, the following words:

The burden of responsibility that falls on me at this dramatic moment in Polish history is great. It is my duty to take on this responsibility - the future of Poland, for which my generation fought on all fronts of the war and to which it gave the best years of its life. History will evaluate our actions." (Jaruzelski 1981)

Tischner's approach to responsibility refers to two philosophical categories: Hegel's 'spirit' and Kant's 'power of judgment.' He asks:

Is it possible to do without the notion of the spirit in the understanding of history? Hegel cannot. Meanwhile, our times are free of this coercion.... Has giving up the notion of the spirit made us wiser? Do we understand man and his history better when [we are] poorer by this one notion? (Tischner 2016, p. 27)

Basically, what is being discuessed here is a general tendency towards cultural secularization; but its special case is the persistent rejection of the spiritual dimension of existence by left-wing circles, including those who, at that time, were in power in Poland. This leftist secularism entails, Tischner concluded, a radical shallowing of the idea of historical responsibility for decisions whose direct effects influence the entire nation. From Hegel's thought, the author of Spowiedż rewolucjonisty derives the idea of a transcendent source of responsibility:

Let us make the words power of judgment the guiding thread of our search. We have an unclear conviction that somewhere among us and above us there 'lives' and 'floats' some power that can 'judge' man for what he does or does 
not do in history. Believers see it as God. Non-believers talk about Humanity, History, the Nation. These words give us the insistent thought that the history of the world is more than a stream of disordered events - it is something that has some sense and can be subject to judgment.... As time passes, the increasingly objective and absolute 'power of judgment', the purpose of which is to formulate an irrevocable judgment, becomes evident. (Tischner 2016, pp. 27-28)

\section{Politics as a spiritual act that is subject to the transcendent power of judgment}

The metapolitical conclusions of this excursion in Hegel's direction are as follows: in politics, it is not enough to have a kind of legitimacy for one's own actions that refers to the historical hic et nunc. Politics is, in a specific sense, a spiritual act. This, in turn, has one more consequence:"The spirit is what allows me, you, him, you and them-all of us to say: we" (Tischner 2016, p. 28).

Developing this thought, the author quotes a fragment of a commentary to Jean Hyppolite's Phenomenology of the Spirit:

The Spirit... presupposes exceeding the particular consciousness and at the same time maintaining its diversity.... Each is for himself and at the same time for his neighbour, each - in order to be himself - requires recognition from the other and each must also require recognition from the other. (Hyppolite 1946, p. 311; quoted in Tischner 2016, p. 29)

Ultimately, therefore, Hegel and his philosophy turn out to be a necessary starting point if we want to base our reflection of politics not only on ethics, but also on anthropology, of the sort Tischner had been developing for some time: the anthropology of human drama, in which the basic categories are dialogue and reciprocity, and the space in which the drama takes place "determines not only the moral order, but also the possible order, i.e. the possible coexistence of beings" (Tischner 1998a, p. 283). The following words confirm this direction of metapolitical thinking:

However, the starting point for our analyses must be Hegel's philosophy, because it is the open or less open horizon of all modern human philosophies. The guiding thread of our analysis is the question of the essence of reciprocity. The philosophies mentioned above bring with them a number of keys, fundamental formulas in which they describe what is most basic for a human being. What is most basic also determines the way of human participation in the drama of life. (Tischner 1986, pp. 10-11)

It is worth noting that in the background of these reflections, of which the tragic events of martial law became an important (though not unique) stimulus, aesthetic associations appear, quite unexpectedly. The very category of the power of judgment, which Tischner exploits here, appears in Kant's works in the context of his 
deliberations on the essence of beauty (see Kant 1790). The metaphor of drama, which Tischner uses as the basis for his anthropological considerations, comes from the field of literature. In these references, one can hear the echo of the Greek kalokagathia: what is good should also be beautiful, and man as a subject of knowledge and experience of beauty also has the ability to judge. Tischner explains:

Immanuel Kant, developing his philosophy of experiencing beauty, links it directly with the Urteilskraft. The word 'power' [Kraft] and the word 'judgment' [Urteil] are deeply justified here. The experience of beauty... is a judgment of the world, [and] judgment is more than just a theoretical judgment: it is an introduction to thinking of the hierarchical dimension. In judgments, people and objects appear to us as more or less worthy of reverence, admiration, or possibly contempt and disgust. The power of judgment is not the power to confirm reality, but the power to establish ideals. What is established is more fundamental than what is given. (Tischner 2004, pp. 13-14)

This hidden reference to the idea of kalokagathia leads to a certain vision of politics as not only a spiritual act, but also as spiritual beauty. Politics-in Tischner's vision-should first be a 'power to establish ideals' and then only be the current activity in the sphere of social practice. One can see (as Stawrowski does) the existence of an internal tension in Tischner's thought and work. On the one hand, he aspires to construct an author's vision of an 'ideal politics' that would meet all theundoubtedly exorbitant —ethical and anthropological requirements derived from Hegel's phenomenology of spiritual life and from the axiological foundations of his own drama philosophy. On the other hand, as the years passed, polemic passion had become more and more common, becoming directly involved in political disputes (without the prefix 'meta-'). Here is a sample of such a polemical style:

The fact [that the communists are still in power] casts a deep shadow over the criticism of 'post-communism' by the 'democrats', because it gives rise to a suspicion that the energy with which they claim ethics is not about ethics but about power.... After the fall of communism, the old opposition divided and argued,... which must have entailed the political collapse of the right wing. Today, the one who is full of guilt himself is screaming: 'catch the guilty.' (Tischner 1997, p. 38)

Stawrowski wrote about this type of situation: "we were not dealing with evolution and change of his views, but with their splitting. At the same time, there were two Tischners simultaneously like Dr. Jekyll and Mr. Hyde" (Stawrowski 2004, p. 73).

\section{Between utopia and hope}

As a result of this contrast, the idealized and detached character of Tischner's vision is all the more striking and attractive. This does not mean that it is completely utopian. It means, however, that its possible realization requires the occurrence of circumstances that do not happen every day, and which we have not yet seen. Perhaps 
the final answer to Tischner's third metapolitical question should be: Polish politics simply lacks happiness. In developing this idea, there is no successful arrangement of historical and social circumstances that would open the political scene to the free activity of people who think and feel in a way consistent with Tischner's understanding of the culture of public life. This is the following understanding:

In the very way we participate in social life, there is an ethic, a social ethos. This ethos is a part of ourselves, an integral part of our conscience, our inner light that allows us to read the essential sense of the drama that is happening around us, a voice that dictates the direction of our commitment... builds our inner self, our anxiety, our dreams, the bitterness of our professions. (Tischner 1982, p. 453)

The internal light postulated here enables us to see that everything that a politically engaged individual does is subject to an absolute judgment, independent of the current economic situation, particular interests, worldview, ideology, political program, etc. The criteria for this judgment are purely ethical, i.e. embedded in the environment of the spirit and in Kant's absolute goodwill. And its subject is a (mysterious and undefined, but as real as possible) transcendent force, which acts as a 'guarantor' of the moral ethos of political life. This ethos should emerge from the depths of human self-awareness, provided that there are conditions for it to do so.

This is not just wishful thinking: historical precedents can be invoked to defend this hope. A similarly happy set of circumstances has happened twice in the recent history of Poland. Once, after more than a hundred years of captivity, it was possible to regain independence owing to the coincidence of favourable factors and the consistent work of the national elite in 1918; and the second time, following the political convulsions caused by the introduction of martial law, it was possible - again owing to the incredibly successful arrangement of external conditions combined with the hard and cleverly thought-out work of Poles-to make the country independent of the influence of its great and invasive eastern neighbour, in order to lead Poland on the path of sovereign politics. This justifies the hope that in the future we will face another breakthrough, owing to which Tischner's project of 'ideal politics' will be able to come true as a beautiful and spiritual act realizing the essence of interpersonal reciprocity.

Funding This study was funded by a University of Silesia internal grant.

\section{Compliance with ethical standards}

Conflict of interest The author declares that he has no conflict of interest.

Open Access This article is distributed under the terms of the Creative Commons Attribution 4.0 International License (http://creativecommons.org/licenses/by/4.0/), which permits unrestricted use, distribution, and reproduction in any medium, provided you give appropriate credit to the original author(s) and the source, provide a link to the Creative Commons license, and indicate if changes were made. 


\section{References}

Bobko, A. (2004). Myślenie religijne a myślenie polityczne [Religious Thinking and Political Thinking]. In J. Jagiełło, W. Zuziak (Eds.), „Badź wolność twoja”. Józefa Tischnera refleksja nad życiem publicznym [ “Be Your Freedom”. Józef Tischner's reflection on public life] (pp. 31-43). Kraków: Znak.

Bonowicz, W. (2001). Tischner. Kraków: Znak.

Bonowicz, W. (2005). Editor's Note. In J. Tischner (Ed.), Etyka solidarności oraz Homo sovieticus [Ethics of Solidarity and Homo Sovieticus] (2nd ed., pp. 285-291). Kraków: Znak.

Gowin, J. (2003). Religia i ludzkie biedy. Ks. Tischnera spory o Kościót [Religion and Human Poverty. Father Tischner's Disputes about the Church]. Kraków: Znak.

Gregor, A. James. (2014). An Introduction to Metapolitics. A Brief Inquiry into the Conceptual Language of Political Science. Cambridge: Cambridge University Press.

Heywood, A. (2004). Political Theory. An Introduction. London-New York: Palgrave Macmillan.

Hyppolite, J. (1946). Genèse et structure de la "Phénoménologie de l'Esprit" de Hegel. Paris: Aubier.

Jagiełło, J. (2005). Introduction. In J. Jagiełło, W. Zuziak (Eds.), „Badź wolność twoja”. Józefa Tischnera refleksja nad życiem publicznym ["Be Your Freedom”. Józef Tischner's Reflection on Public Life] (pp. 9-18). Kraków: Znak.

Jaruzelski, W. (1981). Speech on the Introduction of Martial Law. https://sciaga.pl/tekst/80624-81-przem owienie_generala_jaruzelskiego_o_wprowadzeniu_stanu_wojennego. Accessed 25 April 2019.

Kant, I. (1790). Kritik der Urteilskraft. https://gutenberg.spiegel.de/buch/kritik-der-urteilskraft-3507 Accessed 25 April 2019.

Karoń-Ostrowska, A. (2003). Spotkanie. Z ks. Józefem Tischnerem rozmawia Anna Karoń-Ostrowska [Encounter. Anna Karoń-Ostrowska talks to Father Józef Tischner]. Kraków: Znak.

Kofta, M., \& Leszczyński, A. (Eds.). (2019). Psychologia Okragłego Stołu [Round Table Psychology]. Sopot: Smak Słowa.

Piasecki, A., \& Michalak, R. (2016). Polska 1945-2015: historia polityczna [Poland 1945-2015: Political History]. Warszawa: Wydawnictwo Naukowe PWN.

Pięta-Szawara, A. (Ed.). (2013). Metapolityka: pomiędzy filozofia teoria i praktyka [Metapolitics: Between Philosophy, Theory and Practice]. Rzeszów: Wydawnictwo Uniwersytetu Rzeszowskiego.

Stawrowski, Z. (2004). O pewnej fundamentalnej iluzji. Polemiczny komentarz do myślenia politycznego Józefa Tischnera [About Some Fundamental Illusion. A Polemical Commentary on the Political Thinking of Józef Tischner]. In J. Jagiełło, W. Zuziak (Eds.), „Badź wolność twoja”. Józefa Tischnera refleksja nad życiem publicznym [ "Be Your Freedom”. Józef Tischner's Reflection on Public Life] (pp. 65-82). Kraków: Znak.

Tischner, J. (1981a). Etyka solidarności [Ethics of Solidarity]. Kraków: Znak.

Tischner, J. (1981b). Polski ksztatt dialogu [Polish Form of Dialogue]. Paris: Editions Spotkania.

Tischner, J. (1982). Myślenie wedtug wartości [Thinking According to Values]. Kraków: Znak.

Tischner, J. (1986). Filozofia człowieka. Od ontologii człowieka do metafizyki człowieka [Philosophy of Man. From the Ontology of Man to the Metaphysics of Man]. Kraków: Wydawnictwo Wydziału Filozoficznego Akademii Teologicznej.

Tischner, J. (1991). Polski mtyn [The Polish Mill]. Kraków: Wydawnictwo Nasza Przeszłość.

Tischner, J. (1997). Kot pilnujący myszy [Cat Watching the Mouse]. Znak, 7(506), 38-44.

Tischner, J. (1998a). Filozofia dramatu [Philosophy of Drama]. Kraków: Znak.

Tischner, J. (1998b). Afterword. In A. Michnik (Ed.), Kościót, Lewica, Dialog [Church, Left Wing, Dialogue] (pp. 345-362). Warszawa: Świat Książki.

Tischner, J. (2004). Myślenie w żywiole piękna [Thinking in the Element of Beauty]. Kraków: Znak.

Tischner, J. (2005). Etyka solidarności oraz Homo sovieticus [Ethics of Solidarity and Homo Sovieticus]. Kraków: Znak.

Tischner, J. (2016). Spowiedź rewolucjonisty [Confession of a Revolutionary]. Kraków: Znak.

Weber, M. (1992). Politik als Beruf. Ditzingen: Reclam.

Wisniewski, L. (2019). Ostrzegam [Warning]. Tygodnik Powszechny, 5(3630), 12-15.

Publisher's Note Springer Nature remains neutral with regard to jurisdictional claims in published maps and institutional affiliations. 